\title{
EFEK ANTIDIABETIK EKSTRAK ETANOL DAUN MAHKOTA DEWA (Phaleria macrocarpa) PADA TIKUS DIABETES YANG DIINDUKSI STREPTOZOTOSIN
}

\author{
ANTIDIABETIC EFFECTS OF MAHKOTA DEWA (Phaleria macrocarpa) LEAF \\ ETHANOL EXTRACT IN DIABETIC RAT WITH STREPTOZOTOSIN INDUCTION
}

\author{
Ira Cinta Lestari \\ Bagian Histologi Fakultas Kedokteran Universitas Islam Sumatera Utara \\ Korespondensi : dr.Ira Cinta Lestari, M.Sc. Email : iracinta.lestari@fk.uisu.ac.id
}

\begin{abstract}
ABSTRAK
Daun mahkota dewa (Phaleria macrocarpa) diketahui memiliki efek anti hiperglikemik dengan menghambat aktivitas enzim pencerna karbohidrat $\alpha$-glucosidase, namun efeknya pada kondisi diabetes belum diketahui. Penelitian ini bertujuan untuk mengetahui efek antidiabetik ekstrak etanol daun mahkota dewa (EEDMD) terhadap berat badan dan kadar glukosa darah tikus model diabetes. Studi eksperimental dengan rancangan post test only control group design dilakukan terhadap subjek 45 ekor tikus Sprague Dawley. Subjek dikelompokkan dalam kontrol normal, kontrol diabetes diberi pelarut dan diabetes diberi $7 \mathrm{mg} / 200 \mathrm{~g}, 14 \mathrm{mg} / 200 \mathrm{~g}$, and $28 \mathrm{mg} / 200 \mathrm{~g}$ EEDMD secara peroral, sekali sehari selama 3, 14 dan 25 hari. Model tikus diabetes dibuat dengan injeksi streptozotosin dan nicotinamide. Hasil analisa statistik berat badan dan kadar glukosa puasa antar kelompok terdapat perbedaan yang signifikan. Sehingga kesimpulan penelitian ini adalah pemberian EEDMD memiliki efek antidiabetik pada tikus diabetes yang dinduksi stretozotosin.
\end{abstract}

Kata kunci: Diabetes Mellitus, Phaleria Macrocarpa, Ekstrak Etanol, Streptozotosin, Antidiabetik

ABSTRACT

Phaleria macrocarpa leaf has been known to have anti-hyperglycemic effects by inhibiting the activity of a-glucosidase carbohydrates digestive enzyme, but the systemic effect on diabetic condition is unknown yet. This study was conducted to investigate the antidiabetic effect of ethanolic extract of Phaleria macrocarpa leaf (EEPML) on body weight and blood glucose levels of diabetic rat model. This was a quasi experimental study with post test only control group design. Fourty five male Sprague Dawley rats were classified into normal control group, diabetic control group with solvent, diabetic with $7 \mathrm{mg} / 200 \mathrm{~g}, 14 \mathrm{mg} / 200 \mathrm{~g}$, and $28 \mathrm{mg} / 200 \mathrm{~g}$ of EEPML peroral administration, once a day for 3, 14 and 25 days. The diabetic rat model was made by streptozotocin and nicotinamide injection. Results : Statistical analysis of mean body weight and fasting blood glucose level showed there were significant differences between treatment groups. Conclusion : Administration of EEPML is able to affect the body weight and blood glucose level of diabetic rat model.

Keywords: Diabetes Mellitus, Phaleria Macrocarpa, Ethanolic Extract, Streptozotocin, Antidiabetic

\section{PENDAHULUAN}

Diabetes Mellitus (DM) adalah sindroma gangguan metabolisme karbohidrat, lemak dan protein. Diabetes Mellitus terjadi akibat keterbatasan insulin dan menurunnya sensitifitas jaringan terhadapinsulin. Kondisiinimenyebabkan terjadinya hiperglikemia dan abnormalitas lemak serta berbagai komplikasi seperti gagal ginjal, gangguan kardiovaskular, kebutaan dan non-fatty liver (Abel-Salam, 2012; Yang et al., 2016).
Jumlah penderita DM meningkat secara dramatis dalam 20 tahun terakhir. Proyeksi WHO memperkirakan bahwa populasi DM akan meningkat menjadi 300 juta pada tahun 2025 (Wild et al., 2004). Center for Disease Control and Prevention (CDC) melaporkan terdapat sekitar 21 juta penduduk Amerika Serikat yang menderita DM. Jumlah ini adalah 7\% dari populasi di Amerika Serikat (Khanna et al., 2010). Estimasi prevalensi DM pada seluruh kelompok usia di 
seluruh dunia adalah sebesar $4,4 \%$ atau sekitar 366 juta penderita pada tahun 2030. Prevalensi DM lebih tinggi pada pria daripada wanita dan meningkat pada usia lanjut diatas 65 tahun (Yang et al., 2016).

Diabetes Mellitus terbagi menjadi DM tipe 1 dan DM tipe 2 berdasarkan patogenesisnya. Diabetes Mellitus tipe 1 terjadi akibat kerusakan sel $\beta$ pankreas sehingga insulin gagal diproduksi. Diabetes Mellitus tipe 2 terjadi akibat resistensi insulin di berbagai jaringan dan penurunan sekresi insulin (Drouin et al., 2009; ADA, 2010). Kasus DM tipe 1 hanya terjadi pada 5-10\% kasus DM sedangkan kasus DM tipe 2 menyumbang 90\% dari seluruh populasi DM (Yeo et al., 2011).

Pemanfaatan tanaman obat sebagai terapi tambahan pada kasus diabetes telah banyak dikembangkan. Mahkota dewa (Phaleria macrocarpa) adalah tanaman obat yang berasal dari Papua dan telah banyak digunakan oleh masyarakat Indonesia dan Malaysia. Tanaman ini biasanya digunakan untuk mengobati penyakit diabetes, alergi, liver, vaskular, kanker, gagal ginjal, stroke dan hipertensi. Bagian tanaman yang biasa digunakan adalah batang, daun dan buahnya (Ali et al., 2013; Lay et al., 2014). Uji toksisitas dan uji mutagenitas telah dilakukan terhadap buah mahkota dewa dan terbukti aman untuk digunakan sebagai obat (Zaetun, 2014; Widowati et al., 2005; Widowati et al., 2006).

Daun mahkota dewa mengandung flavonoid, polyphenol, saponin, tannin dan steroid yang memiliki efek anti mikroba (Fariza et al., 2012; Juita, 2004). Phalerin merupakan zat aktif yang terdapat pada daun mahkota dewa dan merupakan zat anti inflamasi (Wahyuningsih et al., 2005; Wijanarko et al., 2005). Ekstrak daun mahkota dewa dilaporkan memiliki efek anti hiperglikemik melalui penghambatan aktivitas enzim $\alpha$-glukosidase yang merupakan enzim pencerna karbohidrat (Sugiwati et al., 2009). Esktrak daun mahkota dewa juga memiliki aktivitas antioksidan, penghambatan tyrosinase dan efek analgetik (Nadri et al., 2014; Tone et al., 2013). Ekstrak etanol daun mahkota dewa juga mampu meningkatkan aktivitas sitotoksik sel NK 1 di lien dan aktivitas fagositosis makrofag pada hewan coba mencit (Ghufron et al., 2008).
Penelitian ini bertujuan untuk mengetahui efek antidiabetik EEDMD terhadap berat badan (BB) dan kadar glukosa (KGD) tikus diabetes yang diinduksi oleh streptozotosin.

\section{METODE}

\section{Pembuatan EEDMD}

Pembuatan ekstrak kental dilakukan dengan metode maserasi menggunakan etanol $70 \%$. Pengenceran ekstrak menggunakan pelarut polyetilen glikol (PEG) 5\%.

\section{Subjek}

Subjek penelitian adalah 45 ekor tikus Sprague Dawley jantan, usia 8 minggu, berat badan 200-230 gram. Subjek dibagi dalam kelompok kontrol non diabetes, kontrol diabetes yang diberi pelarut, diabetes yang diberi EEDMD $7 \mathrm{mg} / 200 \mathrm{~g}, 14 \mathrm{mg} / 200 \mathrm{~g}$ dan $28 \mathrm{mg} / 200 \mathrm{~g}$ BB per oral 1 kali sehari menggunakan intragastric oral tube selama 3, 14 dan 25 hari. Tikus model diabetes dibuat dengan injeksi streptozotosin $65 \mathrm{mg} /$ kgbb i.p dan nicotinamide $100 \mathrm{mg} / \mathrm{Kgbb}$ i.p. Pakan yang diberikan adalah pakan standar dan air minum ad libitum. Penelitian ini telah mendapat persetujuan Komisi etik untuk Penelitian Praklinik Laboratorium Penelitian dan Pengujian Terpadu (LPPT) UGM Yogyakarta.

\section{Pemeriksaan KGD}

Sampel darah diambil dari vena retroorbital tikus dengan menusukan pipet kapiler pada ujung kelopak mata. Darah yang keluar sebanyak $1 \mathrm{~mL}$ dimasukkan ke dalam tabung ukuran $1.5 \mathrm{~mL}$. Serum dan sel darah dipisahkan dengan metode sentrifugasi dengan kecepatan $3500 \mathrm{rpm}$ selama 10 menit. Pemisahan serum ini dilakukan dalam waktu maksimal 1 jam setelah pengambilan darah. Serum yang sudah diambil diperiksa KGD-nya menggunakan metode GOD PAP yang merupakan enzymatic photometric test. Serum sebanyak $10 \mu \mathrm{L}$ dimasukkan ke dalam tabung reaksi yang terbuat dari kaca, ditambahkan reagen glucose GOD FS (DiaSys, 125009910) sebanyak 1000 
$\mu \mathrm{L}$. Inkubasi dilakukan pada suhu 20$25^{\circ} \mathrm{C}$ selama 20 menit. Absorbansi dibaca pada spektrofotometer dengan panjang gelombang $500 \mathrm{~nm}$. Hasilnya yang tertera pada layar monitor dicatat di lembar observasi dalam satuan $\mathrm{mgl} / \mathrm{dL}$.

\section{Analisis Data}

Data BB dan KGD ditampilkan rerata \pm simpangan baku-nya. Normalitas distribusi data diuji menggunakan Shapiro Wilk. Data terdistribusi normal dilakukan uji one way Anova dan post hoc Tukey. Data tidak terdistribusi normal, dilakukan uji non parametrik Kruskal Wallis dan post hoc Mann Whitney.

\section{HASIL DAN PEMBAHASAN}

\section{Karakteristik Umum Hewan Coba}

Pembuatan model tikus diabetes sebagai hewan coba berhasil dilakukan. Tikus yang diinduksi diabetes mengalami peningkatan rerata KGD puasa $(>170 \mathrm{mg} / \mathrm{dL})$ serta penurunan rerata BB.

Perilaku tikus yang diinduksi diabetes menjadi tidak lincah. Tikus yang diinduksi diabetes juga mengalami peningkatan volume air minum dan volume urin. Hal ini terlihat dari wadah penampungan kotoran tikus normal yang tampak kering sedangkan wadah penampungan kotoran tikus diabetes tampak adanya genangan urin. Selama proses penelitian berlangsung tidak ada tikus yang mati.

\section{Pengaruh Pemberian EEDMD terhadap Berat Badan}

Pengukuran BB tikus dilakukan setiap 3 hari sekali selama penelitian berlangsung. Hasil pengukuran $\mathrm{BB}$ menunjukkan bahwa kelompok kontrol normal mengalami peningkatan rerata BB mulai dari awal hingga hari ke-25 pemberian ekstrak, sedangkan kelompok kontrol DM yang diberi pelarut mengalami penurunan rerata $\mathrm{BB}$ mulai hari ke-4 setelah induksi hingga hari ke25 pemberian ekstrak. Kelompok DM yang diberi EEDMD dosis 1, 2 dan 3 juga mengalami penurunan rerata $\mathrm{BB}$ mulai hari ke-4 setelah induksi hingga hari ke-25 pemberian ekstrak (Gambar 1).

Hasil analisis statistik rerata BB terakhir menggunakan metode one way Anova menunjukkan terdapat perbedaan yang signifikan antar kelompok perlakuan (nilai $\mathrm{p}=0,03$ ) (Tabel 1). Hal ini menunjukkan pemberian EEDMD mempengaruhi BB pada model tikus diabetes.

\section{Pengaruh Pemberian EEDMD terhadap Kadar Glukosa Darah}

Pemeriksaan KGD puasa tikus dilakukan pada saat awal sebelum induksi, hari ke-8 setelah induksi serta hari ke-3, 14 dan 25 pemberian ekstrak. Hasil pemeriksaan KGD puasa menunjukkan bahwa kelompok kontrol normal tidak mengalami peningkatan rerata KGD puasa mulai dari awal hingga hari ke-25 pemberian ekstrak (Gambar 2).

KGD puasa kelompok kontrol DM yang diberi pelarut mengalami peningkatan pada hari ke-8 induksi setelah induksi. Rerata KGD puasa semakin meningkat pada hari ke-14 pemberian ekstrak kemudian terjadi penurunan rerata KGD puasa pada hari ke-25 namun tetap dalam batas diabetes yaitu $>170 \mathrm{mg} / \mathrm{dL}$ (Gambar 2).

Kelompok DM yang diberi EEDMD dosis 1 dan 2 mengalami peningkatan rerata KGD puasa pada hari ke-8 induksi dan hari ke-3 pemberian ekstrak kemudian terjadi penurunan rerata KGD puasa pada hari-14 dan 25 namun tetap dalam batas diabetes (Gambar 2).

Kelompok DM yang diberi EEDMD dosis 3 mengalami peningkatan rerata KGD puasa pada hari ke-8 induksi kemudian terjadi penurunan rerata KGD puasa pada hari-3, 14 dan 25 pemberian ekstrak namun tetap dalam batas diabetes (Gambar 2).

Hasil analisis statistik rerata KGD puasa terakhir menggunakan uji non parametrik Kruskal Wallis menunjukkan terdapat perbedaan yang signifikan antar kelompok perlakuan (nilai $\mathrm{p}=0,007$ ) (Tabel 1). Hal ini menunjukkan pemberian EEDMD mempengaruhi KGD puasa pada model tikus diabetes. 
Tabel 1. Data Hasil Penelitian

\begin{tabular}{cccc}
\hline \multicolumn{2}{c}{ Kelompok } & \multicolumn{2}{c}{ Parameter } \\
\hline Terminasi & Perlakuan & Berat Badan Terakhir (gram) & KGD Puasa Terakhir (g/dL) \\
\hline H-3 & DM & $225,9 \pm 27,79$ & $84 \pm 6,93$ \\
& DM-MD1 & $159,87 \pm 19,46$ & $308 \pm 100,5$ \\
& DM-MD2 & $173,17 \pm 34,02$ & $316 \pm 62,39$ \\
& DM-MD3 & $186,2 \pm 16,29$ & $233,67 \pm 129,34$ \\
H-14 & $198,93 \pm 16,35$ & $260,33 \pm 33,26$ \\
& DM & $250,17 \pm 43,63$ & $92,67 \pm 5,86$ \\
& DM-MD1 & $168,97 \pm 18,53$ & $376 \pm 152,33$ \\
& DM-MD2 & $143,03 \pm 10,07$ & $311,33 \pm 103,32$ \\
& DM-MD3 & $178,03 \pm 4,87$ & $390 \pm 134,84$ \\
& N & $197,13 \pm 26,12$ & $353,33 \pm 174,70$ \\
& DM & $256,5 \pm 14,25$ & $78 \pm 16,82$ \\
H-25 & DM-MD1 & $165,9 \pm 32,85$ & $320,67 \pm 94,11$ \\
& DM-MD2 & $193,9 \pm 26,08$ & $250,67 \pm 76,29$ \\
& DM-MD3 & $163,67 \pm 23,41$ & $204 \pm 21,38$ \\
& Nilai $p$ & $205,77 \pm 84,89$ & $209,33 \pm 23,12$ \\
\hline
\end{tabular}

Sebaran data diuji dengan Saphiro-Wilk. Data disajikan dalam rerata \pm simpangan baku.

$\mathrm{N}$ : Kontrol normal; DM : Kontrol DM diberi pelarut; DM-MD : DM diberi ekstrak dosis 1, 2 dan 3. *Uji beda nyata one way Anova, $\mathrm{p}<0,05$ berbeda bermakna. **Uji non parametrik Kruskal Wallis, $\mathrm{p}<0,05$ berbeda bermakna.

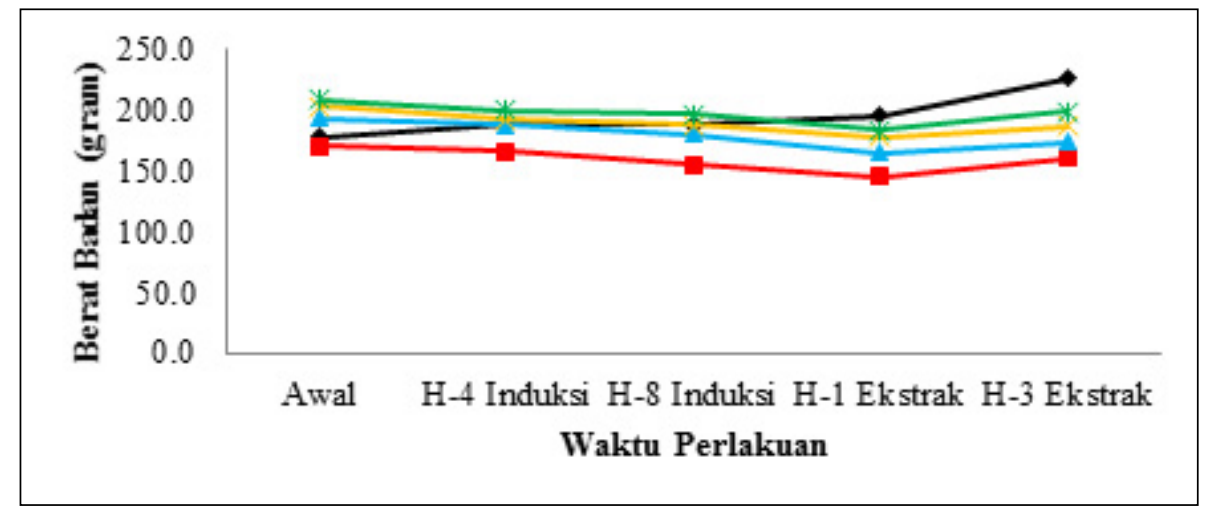

(A)

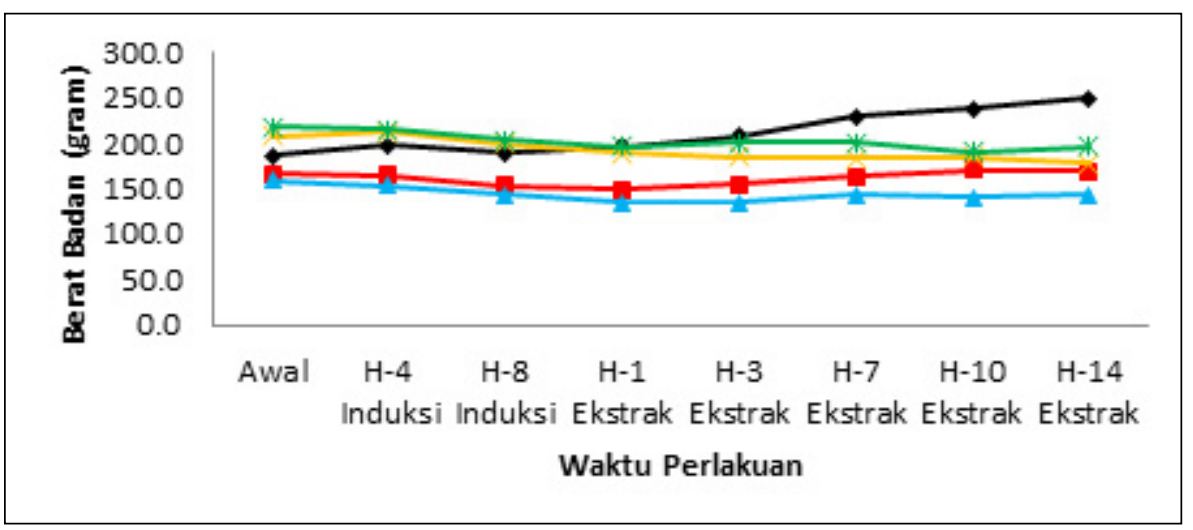

(B) 


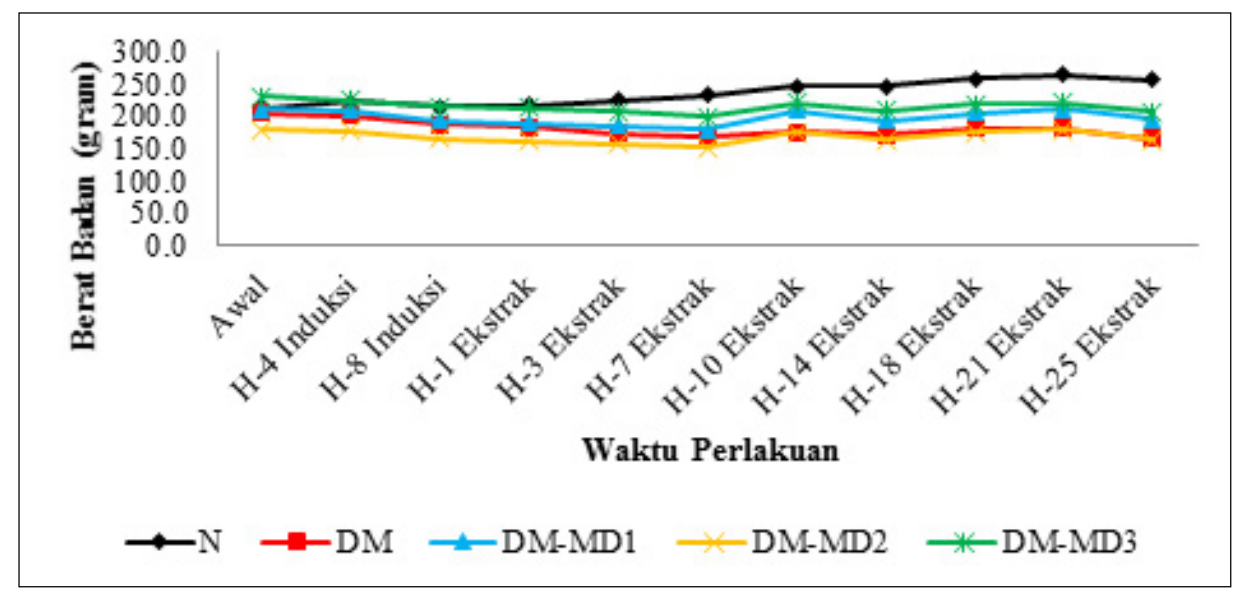

(C)

Gambar 1. Perubahan rerata berat badan tikus kelompok terminasi hari ke-3 (A), hari ke-14 (B) dan hari ke-25 (C). N : Kontrol normal; DM : Kontrol DM diberi pelarut; DM-MD: DM diberi ekstrak dosis 1, 2 dan 3.

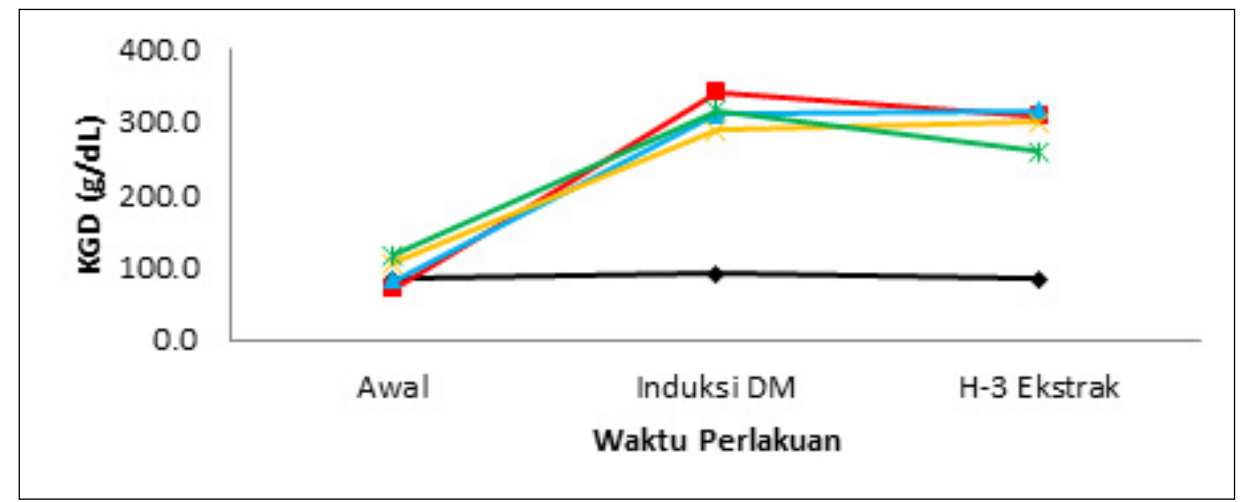

(A)

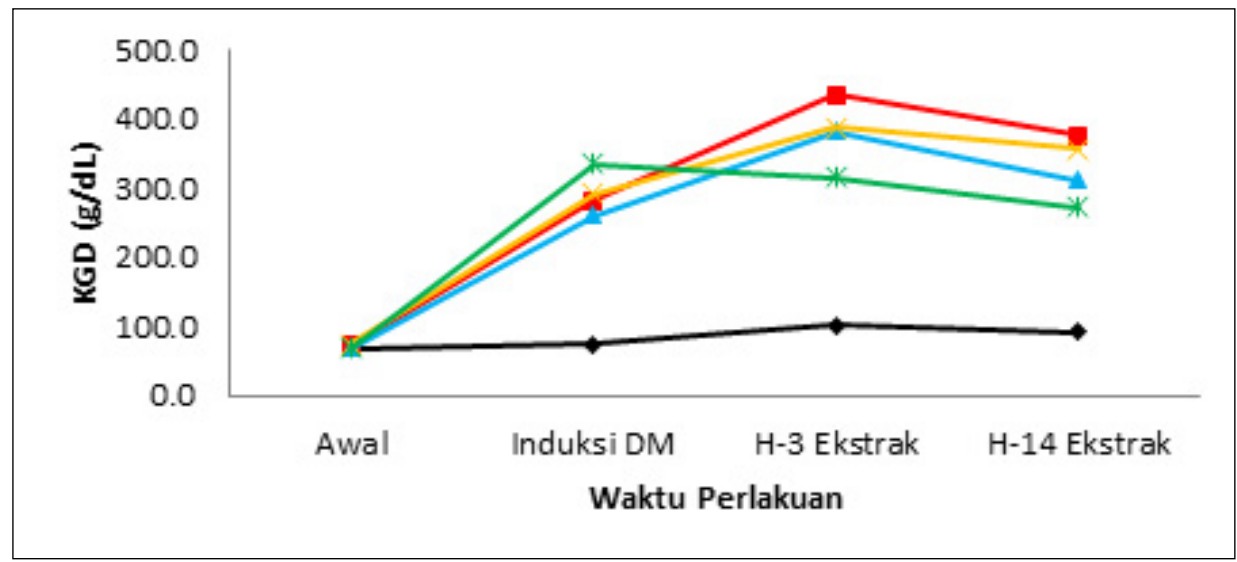

(B) 


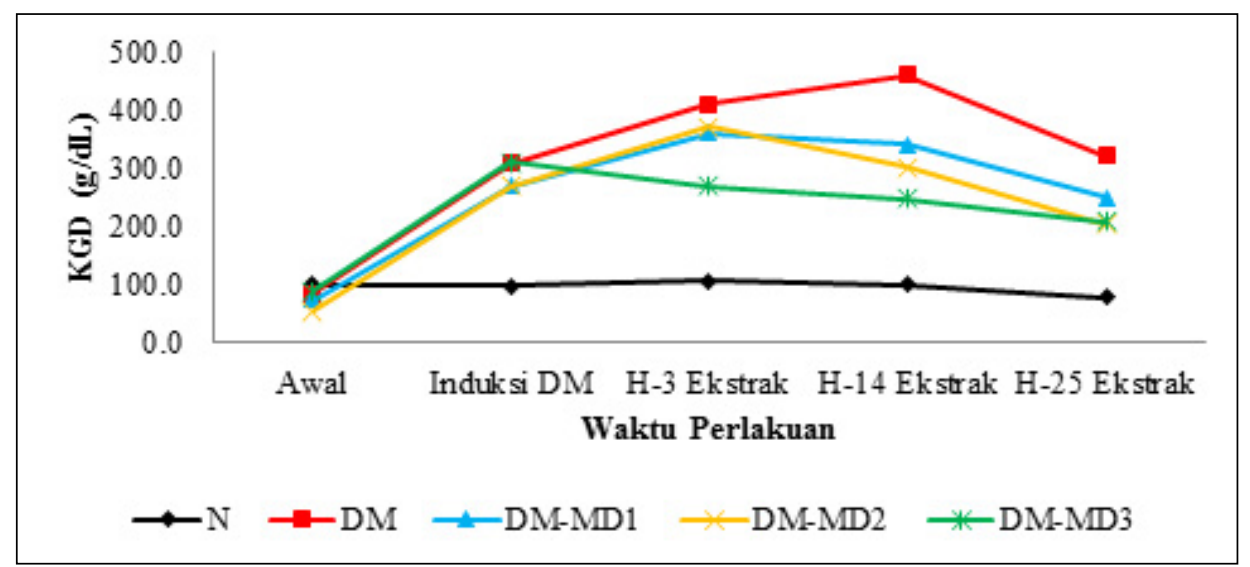

(C)

Gambar 2. Perubahan rerata kadar glukosa darah puasa tikus kelompok terminasi hari ke-3 (A), hari ke-14 (B) dan hari ke-25 (C). N : Kontrol normal; DM : Kontrol DM diberi pelarut; DM-MD : DM diberi ekstrak dosis 1, 2 dan 3.

Pembuatan model tikus diabetes pada penelitian ini menggunakan agen diabetogenik streptozotosinyangdapatmengakibatkankerusakan langsung pada sel $\beta$ pankreas yang merupakan penghasil hormon insulin. Streptozotosin masuk ke dalam sel $\beta$ pankreas melalui trasporter glukosa GLUT 2 kemudian dimetabolime oleh sel dan menjadi donor pembentukan nitic oxide (NO). Hal ini mengakibatkan peningkatan oksigen reaktif di dalam mitokondria, menghambat siklus krebs, menurunkan konsumsi oksigen di mitokondria, produksi ATP dan nukleotida pada sel $\beta$ pankreas. Gangguan metabolisme pada sel $\beta$ pankreas tersebut mengakibatkan tikus yang mendapat induksi streptozotosin mengalami hiperglikemia akibat penurunan produksi hormon insulin (Nugroho et al., 2006).

Kombinasi pemberian Streptozotosin dan Nicotinamide dapat mencegah hiperglikemia yang berlebihan dan kematian pada model tikus diabetes. Hal ini terbukti dengan kenaikan KGD puasa model tikus diabetes pada penelitian ini tidak melebihi $500 \mathrm{mg} / \mathrm{dL}$ bahkan terjadi penurunan KGD puasa pada tikus kontrol DM pada hari ke14 dan 25 meskipun masih dalam batas diabetes ( $>170 \mathrm{mg} / \mathrm{dL}$ ) (Gambar 2). Hal ini kemungkinan diakibatkan efek induksi diabetes menggunakan kombinasi streptozotosin dan nicotinamide yang bersifat sementara. Nicotinamide dapat melindungi kerusakan sel $\beta$ pankreas dengan menghambat apoptosis dan pembentukan nitric oxide yang ditimbulkan oleh streptozotosin (Alenzi, 2009).

Hasil pengukuran KGD puasa dan BB yang dilakukan secara berkala menunjukkan bahwa induksi diabetes yang dilakukan terhadap hewan coba mengakibatkan tikus mengalami peningkatan KGD puasa dan penurunan BB (Gambar 1 dan 2). Penurunan $B B$ merupakan salah satu kondisi yang sering menyertai diabetes karena tubuh tidak mampu menggunakan glukosa sebagai sumber energi akibat kekurangan hormon insulin yang berfungsi memasukkan glukosa ke dalam sel. Kondisi ini menginduksi pemecahan cadangan lemak tubuh sebagai kompensasi alternatif substrat untuk menghasilkan energy (Nugroho et al., 2015).

Hasil penelitian ini membuktikan bahwa pemberian EEDMD mampu mempengaruhi BB dan KGD puasa pada model tikus diabetes. Tikus diabetes yang diberi EEDMD mengalami penurunan KGD puasa meskipun masih dalam kondisi diabetes. BB tikus diabetes yang diberi EEDMD juga tetap mengalami penurunan namun lebih stabil jika dibandingkan tikus kontrol diabetes yang hanya diberi pelarut.

Penurunan BB pada tikus diabetes yang diberi EEDMD ini tetap terjadi karena pemberian EEDMD tidak mampu menekan kenaikan KGD puasa yang tinggi pada kondisi diabetes. Meskipun hasil penelitian menunjukkan EEDMD dapat menurunkan KGD puasa tikus diabetes, namun belum dapat mencapai nilai normal. Hal ini kemungkinan diakibatkan efek antidiabetik daun mahkota dewa hanya melalui mekanisme ekstra pankreas sehingga tidak mempengaruhi produksi insulin. Daun mahkota dewa telah terbukti menghambat hiperglikemia post prandial melalui mekanisme penghambatan enzim a-glukosidase yang merupakan enzim pencerna karbohidrat sehingga penyerapan dan transport 
glukosa terhambat. Penelitan ini dilakukan secara phytochemistry (Sugiwati et al., 2009). Penelitian potensi anti hiperglikemik daun mahkota dewa menggunakan model tikus diabetes belum pernah dilakukan sebelumnya.

Efek anti hiperglikemik EEDMD juga dipengaruhi perbedaan dosis EEDMD yang diberikan. Hasil penelitian ini menunjukkan perbedaan dosis EEDMD mempengaruhi onset penurunan KGD puasa pada model tikus diabetes. Semakin tinggi dosis EEDMD yang diberikan maka efek penurunan KGD semakin cepat terjadi. Pemberian EEDMD dosis 3 (28 $\mathrm{mg} / \mathrm{KgBB})$ mengakibatkan penurunan KGD puasa pada hari-3 pemberian ekstrak sedangkan pemberian EEDMD dosis $1(7 \mathrm{mg} / 200 \mathrm{~g})$ dan dosis $2(14 \mathrm{mg} / 200 \mathrm{~g})$ mengakibatkan penurunan KGD puasa pada hari ke-14 dan 25 pemberian ekstrak (Gambar 2).

Hasil penelitian ini menunjukkan bahwa daun makhota dewa berpotensi sebagai terapi tambahan yang dapat mencegah penurunan $\mathrm{BB}$ dan mencegah peningkatan KGD pada kondisi diabetes sehingga layak untuk diteliti lebih lanjut.

\section{SIMPULAN}

Pemberian EEDMD mampu mempengaruhi berat badan tikus dan kadar glukosa darah tikus diabetes yang diinduksi streptozotosin.

\section{DAFTAR PUSTAKA}

Abel-Salam, B.K. 2012. Immunomodulatory effects of black seeds and garlic on alloxan-induced Diabetes in albino rat. Allergol Immunopathol (Madr) 40(6):336-40.

Alenzi, F.Q. 2009. Effect of Nicotinamide on Experimental Induced Diabetes. Iran J Allergy Asthma Immunol 8(1): 11-18.

Ali, R.B., Atangwho, I.J., Kaur, N., Ahmad, M., Mahmud, R., Asmawi, M.Z. 2013. In vitro and in vivo effects of standardized extract and fractions of Phaleria macrocarpa fruits pericarp on lead carbohydrate digesting enzymes. BMC Complement Altern Med. 13:39.

American Diabetes Association (ADA). 2010. Diagnosis and Classification of Diabetes Mellitus. Diabetes Care 33(1).

Drouin, P., Blickle, J.F., Charbonnel, B., Eschwege, E., Guillausseau, P.J., Plouin, P F., Daninos, J.M., Balarac, N., Sauvanet, J.P. 2009. Diagnosis and classification of diabetes mellitus. Diabetes Care :S62-S67.

Fariza, N.I., Fadzureena, J., Zunoliza, A., Chuah, A.L., Pin, K.Y., Adawiyah, I. 2012. Anti-inflamatory Activity of the Mayor Compound from Methanol Extract of Phaleria macrocarpa Leaves. J of App Scie. 12(11): 1195-1198.

Ghufron, M., Soesatyo, M.M., Haryana, Sismindari. 2008. The effects of Ethanol extract isolated from Phaleria macrocarpha on NK1.1 activity. Berkala Ilmu Kedokteran 40:109-118.

Juita, N. 2004. Aktifitas Antibakteri Daun Mahkota Dewa (Phaleria macrocarpa (Scheff.) Boerl.) Terhadap Bakteri P. aeruginosa dan Bacillus cereus Dengan Metode Difusi Agar. Fakultas Farmasi Universitas Padjajaran, Bandung.

Khanna, S., Biswas, S., Shang, Y., Collard, E., Azad, A., Kauh, C., Bhasker, V., Gordillo, G.M., Sen, C.K., Roy, S. 2010. Macrophage dysfunction impairs resolution of inflammation in the wounds of diabetic mice. PloS one 5(3):e9539.

Lay, M.M., Karsani, S.A., Mohajer, S., Abd Malek, S.N. 2014. Phytochemical constituents, nutritional values, phenolics, flavonols, flavonoids, antioxidant and cytotoxicity studies on Phaleria macrocarpa (Scheff.) Boerl fruits. BMC Complement Altern Med. 8(14):152.

Nadri, M.H., Salim, Y., Basar, N., Yahya, A., Zulkifli, R.M. 2014. Antioxidant activities and tyrosinase inhibition effects of Phaleria macrocarpa extracts. Afr J Tradit Complement Altern Med. 11(3):10711.

Nugroho, A.E. 2006. Hewan Percobaan Diabetes Mellitus : Patologi Dan Mekanisme Aksi Diabetogenik. 
Biodiversitas 7(4):378-382.

Nugroho, F.A., Ginting, R.M.S., Nurdiana. 2015. Kadar NF- K $\beta$ Pankreas Tikus Model Type 2 Diabetes Mellitus dengan Pemberian Tepung Susu Sapi. Indonesian Journal of Human Nutrition (2)2 : $91-100$.

Sugiwati, S., Setiasih, S., Afifah, E. 2009. Antihyperglycemic activity of the mahkota dewa leaf. extracts as an alpha-glucosidase inhibitor. J Logika 13(2):74-78.

Tone, D.S., Wuisan, J., Mambo, C. 2013. Uji Efek Analgesik Ekstrak Daun Mahkota Dewa (Phaleria macrocarpa) pada Mencit (Mus musculus) Jurnal e-Biomedik (eBM) 1(2):873-878.

Wahyuningsih, M.S.H., Mubarika, S., Artama, W.T., Wahyuono, S., Ganjar, I.G., 2005. Sitotoksisitas Phalerin hasil isolasi dari daun mahkota dewa (phaleria macrocarpa (scheff) boerl) terhadap berbagai sel kanker manusia in vitro. Majalah Obat Tradisional 10(32):5-9.

Widowati, L., Nugroho, Y.A., Murhandini, S. 2006. Uji Mutagenitas Ekstrak Etanol Mahkota Dewa (Phaleria macrocarpa (Scheeh.) Boerl.). Media Litbang Kesehatan 16(3).

Widowati, L., Pudjiastuti, Nuratmi, B. 2005. Uji Toksisitas Akut Ekstrak Mahkota Dewa pada Hewan Coba. Media Litbang Kesehatan 15(1).

Wijanarko, H., Wahyuono, S., Ganjar, I.G., Hartati, M.S., Mubarika, S. 2005. Aktivitas Phalerin hasil isolasi dari daun mahkota dewa (phaleria macrocarpa (scheff) boerl) sebagai pemicu fagositosis makrofag in vitro. Majalah Obat Tradisional 10(33):11-15.

Wild, S., Roglic, G., Green, A., Sicree, R., King, H. 2004. Global Prevalence of Diabetes : Estimates for the year 2000 and projections for 2030. Diabetes Care 27(5):1047-53.

Yang, J., Zhao, P., Wan, D., Zhou, Q., Wang, C., Shu, G., Mei, Z., Yang, X. 2016. Antidiabetic Effect of Methanolic Extract from Berberis julianae Schneid. via Activation of AMP-Activated Protein Kinase in Type 2 Diabetic Mice. Evid Based Complement Alternat Med. 106206.

Yeo, J., Kang, Y.M., Cho ,S.I., Jung, M.H. 2011. Effects of a multi-herbal extract on type 2 diabetes. Chin Med. 4(6):10.

Zaetun, S. 2014. Uji Toksisitas Sari Buah Mahkota Dewa (Phaleria macrocarpa) pada Hewan Coba Mencit (Mus musculus). Media Bina Ilmiah 8(6). 